\title{
The Impact of Digital Literacy Ability of Islamic Religious Education Students on FIQH Learning Achievements
}

\author{
$1^{\text {st }} \mathrm{N}$ Araniri \\ Pendidikan Agama Islam \\ Universitas Majalengka \\ Jl. Raya K H Abdul Halim No.103, \\ Majalengka Kulon, Kec. Majalengka, \\ Kabupaten Majalengka, Jawa Barat \\ 45418, Indonesia \\ siuddin1308@unma.ac.id \\ $4^{\text {th }} \mathrm{G}$ M Jamaludin \\ Pendidikan Agama Islam \\ Universitas Majalengka \\ Jl. Raya K H Abdul Halim No.103, \\ Majalengka Kulon, Kec. Majalengka, \\ Kabupaten Majalengka, Jawa Barat \\ 45418, Indonesia
}

\author{
$2^{\text {nd }} \mathrm{S}$ Nahriyah \\ Pendidikan Agama Islam \\ Universitas Majalengka \\ Jl. Raya K H Abdul Halim No.103, \\ Majalengka Kulon, Kec. Majalengka, \\ Kabupaten Majalengka, Jawa Barat \\ 45418, Indonesia \\ $5^{\text {th }}$ M G Jatisunda \\ Pendidikan Matematika \\ Universitas Majalengka \\ J1. Raya K H Abdul Halim No.103, \\ Majalengka Kulon, Kec. Majalengka, \\ Kabupaten Majalengka, Jawa Barat \\ 45418, Indonesia
}

\author{
$3^{\text {rd }}$ Nurhidayat \\ Pendidikan Agama Islam \\ Universitas Majalengka \\ Jl. Raya K H Abdul Halim No.103, \\ Majalengka Kulon, Kec. Majalengka, \\ Kabupaten Majalengka, Jawa Barat \\ 45418, Indonesia
}

\begin{abstract}
The spread of the COVID 19 pandemic forced the learning process to take place online. Online-based learning has been proven successful and effective in the educational process. Good digital literacy skills can make it easy for students when the learning process is carried out online. However, not all students' digital literacy skills have good digital literacy abilities. The purpose of this study was to determine the impact that digital literacy has on the learning achievement of FIQH students of Islamic religious education. The method of study is pre-experimental. The research design used is the One-Shot Case Study. The sample of this is study was all pre-service Islamic Religion teacher semester IV academic year 2019/2020. To see the difference in the improvement of each category of student ability is analyzed using a one-way ANOVA. Based on the results of the Anova analysis, digital literacy ability has a positive impact on student learning achievement when the learning process is based online.
\end{abstract}

Keywords—Digital Literacy, Islamic, FIGH, Learning

\section{INTRODUCTION}

Islamic education functionality will prove to be successful when individuals can apply the knowledge, skills, values, etc. that are obtained for practical life [1], [2]. Fiqh (Islamic jurisprudence) is the science that the basic practical knowledge can not be eradicated from every corner of the life of a Muslim. Fiqh contains laws that explain everything related to the procedure of worship. Fiqh is one of the central studies in religious education [3]. Fiqh is studied in formal and non-formal educational institutions such as pesantren, Islamic schools, and public schools, fiqh must be studied and even become the focus of consideration and learning in these educational institutions.

The broad scope of Fiqh requires attention in determining fiqh learning by not choosing haphazardly in determining learning strategies and methods. Determining the plan for providing fiqh content should be meaningful so that it not only touches on the theoretical concepts but also on the practical aspects of everyday life. [4]. During the COVID 19 pandemic, Fiqh must remain professionally transmitted to students, supported by principles and quality teaching. The COVID-19 pandemic has changed the lives of students at various levels of education [5]. This pandemic has seriously affected the higher education system, which is one of the main determinants of the future of a nation [6]. The Government of Indonesia through the Ministry of Education and Culture issued a policy for each level of education to carry out the learning process at home. During this increasingly growing crisis, students, lecturers, and 
learning models need creative approaches and versatility so that the learning cycle will proceed well [7], [8].

The development of digital technology can be used in the field of education, especially the implementation of teaching and learning activities to achieve educational goals [9]. Technology is pedagogically neutral and practicing teaching can be applied very well [10]. Organizing includes setting the learning activities goals, procedural rules, and timetables, be something important to prepare during online learning [11]. The online learning process can pose challenges for students to learn independently, without the help of the teacher on the spot [12]. Students have the skills, experience, interests, attitudes, and understanding of digital devices, information systems, and content [13]. Students who can learn proactively and independently have different advantages in online learning. The growth and evolution of technologies have made several significant changes in literacy over the past two decades [14]. The development of digital literacy has a profound impact on the behavior of their students on learning situations that use technology [15]. It's important to create a digital literacy program that combines social and academic learning in higher education [16].

The component of digital literacy is the integration between information literacy, media literacy, and visual literacy [17]. Digital literacy refers to the knowledge and skills of students needed for professional development and to actively participate in technology-based societies [18]. Digital literacy is an important skill for students at this time [19]. Digital literacy is related to critical thinking when utilizing commonly used technologies such as the Web, social networks, and mobile applications [20]. Students with digital literacy skills can easily reach the level of fluency in using the right digital information [21]. In higher education, this skill is very important for the development of knowledge. Digital literacy skills can provide the basics of managing a digital environment that is needed by college students to succeed [22].

Several studies related to digital literacy have a positive impact on knowledge, understanding, and skills in using the media needed as a source of relevant information [23]. But different results were found that digital skills did not help much to develop the educational performance of students [24]. Other research results students only have digital basic competencies and skills to use information and communication technology at the basic level, they need training on how to use digital so that learning objectives can be achieved properly, then also how to design learning to improve digital literacy skills online learning processes [25]. The purpose of this study was to what extent the impact of digital literacy on student achievement in Fiqh during the online learning process.

\section{METHOD}

The research method used is a pre-experimental method to be the right balance between power, generalization, various types of 'validity' [26]. The research design used was the One-Shot Case Study with the process of group implementation being treated, the dependent variable was then observed (measured) to assess the effect of treatment [27], [28]. Figure 1. shows the research design used.
$\mathrm{X}$

Treatment
$\mathrm{Y}$

Observation

(Dependent Variable)
Fig. 1. Desain One-Shot Case Study [27]

The sample of this is study was all pre-service Islamic Religion teacher semester VI academic year 2019/2020 with 27 students Faculty of Islamic Religion Universitas Majalengka, West Java, Indonesia. The sample is determined by purposive sampling to make it easier to choose representative samples according to the wishes of the researcher. To obtain valid criteria, the instruments in this study were developed with the help of education experts then tested. Development of digital literacy scale based on the following indicators: information literacy, computer literacy, communication literacy, visual literacy, and technology literacy. The results of the scale Self-regulated learning are analyzed using one-way ANOVA to get conclusions.

\section{RESULT AND DISCUSSION}

Measurement of the digital literacy scale is the product of translating the categories of Likert data into data ratio by translating the Method Successive Interval (MSI) process. Based on the results of data processing on the digital literacy scale score, the minimum, maximum, average scores, and standard deviation scores are obtained in the following Table I.

TABLE I. DESCRIPTION OF THE DIGITAL LITERACY SCALE TEST RESULTS

\begin{tabular}{|c|c|c|c|c|}
\hline$N$ & Min. & Max. & Mean & $\begin{array}{c}\text { Std. } \\
\text { Deviation }\end{array}$ \\
\hline 27 & 53 & 121 & 86.88 & 7.76 \\
\hline
\end{tabular}

Digital literacy scale score, the mean of 27 samples is 86,88 with a minimum value of 53 and a maximum of 121 . In the next step, students are grouped by the categorization of digital literacy scale scores, the results are presented in Table II.

TABLE II. DIGITAL LITERACY SCALE CATEGORIZATION

\begin{tabular}{|c|c|c|c|}
\hline Categorization & Stat. & Score & $N$ \\
\hline High & $\overline{\boldsymbol{x}}$ & 116 & 4 \\
\hline Medium & $\overline{\boldsymbol{x}}$ & 89.64 & 14 \\
\hline Low & $\overline{\boldsymbol{x}}$ & 55 & 9 \\
\hline
\end{tabular}

Based on Table II. there are 4 high-level students, the middle-level group is 14 and the low-level group is 9 students. The next step is the final results of the Fiqh test of 
the students grouped by the categorization of digital literacy scale scores, the results are presented in Table III.

TABLE III. FINAL FIQH TEST RESULTS BASED ON DIGITAL LITERACY SCALE

\begin{tabular}{|c|l|l|l|}
\hline Categorization & Mean & Std. Deviation & $N$ \\
\hline High & 70.44 & 2.06 & 4 \\
\hline Medium & 55.60 & 4.82 & 14 \\
\hline Low & 44.24 & 3.20 & 9 \\
\hline Total & 78.44 & 5.41 & 27 \\
\hline
\end{tabular}

Based on Table III. descriptive analysis can we conclude, that the average final test of Fiqh of students with high digital literacy category gets the highest average final test when compared to the medium and low category of digital literacy. This means that descriptively students who have a high category of digital literacy are more successful in achieving learning objectives. Subsequent analysis to determine the significant difference in the final fiqh test was carried out using the one-way ANOVA test, the results are presented in Table IV.

TABLE IV. ONE-WAY ANOVA TEST

\begin{tabular}{|l|r|r|r|r|r|}
\hline Digital Literacy & $\begin{array}{c}\text { Sum of } \\
\text { Squares }\end{array}$ & \multicolumn{1}{|c|}{ df } & $\begin{array}{c}\text { Mean } \\
\text { Square }\end{array}$ & $F$ & Sig. \\
\hline Between Groups & 12003.78 & 2 & 6001.39 & 54.37 & .000 \\
\hline Within Groups & 2549.22 & 24 & 110.38 & & \\
\hline Total & 14563.00 & 26 & & & \\
\hline
\end{tabular}

Based on Table IV. the conclusion is obtained that the final fiqh test students in the three categories obtained sig. < 0.05 then $H_{o}$ is rejected so there is a significant difference in the final fiqh test based on category digital literacy scale. To see the difference in the final fiqh test in each category of digital literacy scale, to see the difference is done by Post hoc test using Tamhane test. The results of Tamhan's post hoc calculations are presented in Table $\mathbf{V}$.

TABLE V. TAMHANE POST HOC

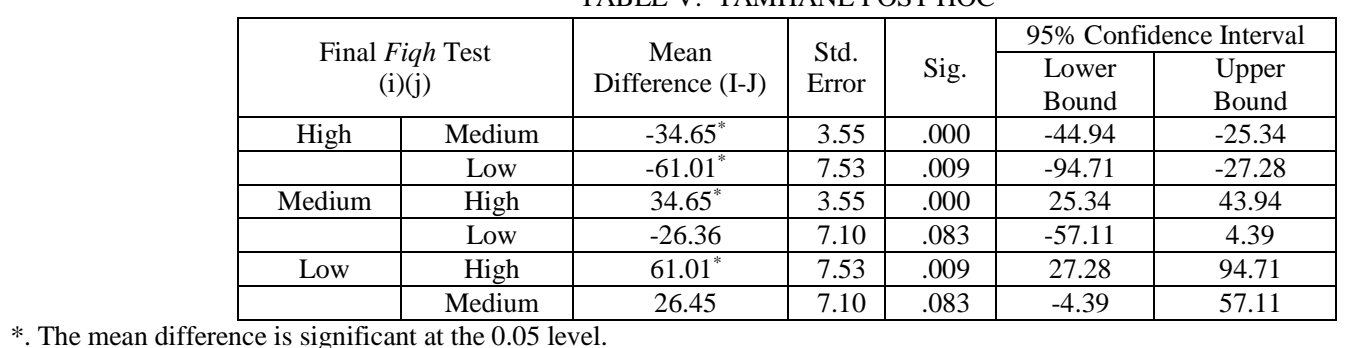

Based on Table V. Post Hoc LSD results above, for each final fiqh test comparison between each category of students based on the digital literacy scale, get a sig. $<0.05$ then Ho is rejected. Thus the final fiqh test in each digital literacy scale category is significantly different. The high category of fiqh final test differs significantly from the moderate and low category of the final fiqh test, then the final category of the fiqh test differs significantly from the high and low category. Finally, the low category of final fiqh tests differs significantly from the high and medium categories.

The data analysis process starts from the one-way ANOVA test and also the more detailed post hocTamhane test to see any significant differences in the final fiqh test based on the digital literacy scale category. This provides information to researchers regarding the implementation of online-based learning processes, that with students with good digital literacy skills, they provide higher learning achievement compared to low digital literacy skills. The results of research conducted on digital literacy capability is a necessity, namely data literacy, technology literacy, and information literacy to be able to utilize optimal utilization [29]. The results of other studies also provide information to us, relating to digital literacy capabilities that significantly differences learning achievement in high school students [30]. Then research conducted at the elementary school level provides information, that each respondent interviewed, that they realize with digital literacy skills will make it easier for them to learn online [31]. The results of studies from various levels of education strengthen that when the learning process is carried out online, the role of digital literacy skills is very important for students' success in achieving learning goals.

\section{CONCLUSION}

Based on descriptive analysis, students in the category of high digital literacy ability have high final Fiqh tests as well. These results are reinforced by one-way ANOVA inference analysis with the results of strengthening the descriptive analysis, the results where there are significant differences in the final results of the fiqh student test. Then based on the post hoc test also provides information that there are differences in final Fiqh tests in each category of digital literacy ability of students, where the high category differs significantly from the medium and low categories, as well as 
for the medium category significantly different from the low and high categories. The conclusion from the whole is that digital literacy ability has a positive impact on student learning achievement when the learning process is based online. This research was conducted with various access limitations due to the COVID 19 pandemic. To be more comprehensive, further research was carried out with two classes, namely the experimental class, and the control class so that it was clearer to see each difference measured.

\section{ACKNOWLEDGMENTS}

The implementation of this research is inseparable from the support of Majalengka University Rector, therefore we thank you for the support of research funding.

\section{REFERENCES}

[1] R. Abdulhamid and others, "The Prospects of Islamic Education Curriculum: The Case of University of Abuja," Ta'dib J. Islam. Educ. (Jurnal Pendidik. Islam., vol. 22, no. 1, pp. 87-95, 2017.

[2] M. N. S. Syah, "MUSLIM WORLD: HISTORICAL, POLITICAL, AND SOCIO-CULTURAL PERSPECTIVE," QIJIS (Qudus Int. J. Islam. Stud., vol. 4, no. 1, pp. 82-105, 2016.

[3] S. Hasanova, "A Qualitative Evaluation on Fiqh Education from \{\.I\}mam Hatip High Schools to Theology Faculties," in SHS Web of Conferences, 2018, vol. 48, p. 1054.

[4] F. Y. Haryani, M. F. Hidayatullah, M. Yusuf, and Asrowi, "Problem-based learning for teaching Fiqh: An overview of its impact on critical thinking skill," in AIP Conference Proceedings, 2019, vol. 2194, no. 1, p. 20038.

[5] S. J. Daniel, "Education and the COVID-19 pandemic," Prospects, pp. 1-6, 2020.

[6] J. Crawford, K. Butler-Henderson, J. Rudolph, M. Glowatz, and others, "COVID-19: 20 Countries' Higher Education Intra-Period Digital Pedagogy Responses," J. Appl. Teach. Learn., vol. 3, no. $1,2020$.

[7] R. C. Chick et al., "Using Technology to Maintain the Education of Residents During the COVID-19 Pandemic," J. Surg. Educ., 2020 .

[8] Z. Almarzooq, M. Lopes, and A. Kochar, "Virtual learning during the COVID-19 pandemic: a disruptive technology in graduate medical education." Journal of the American College of Cardiology, 2020

[9] R. Rizal, D. Rusdiana, and W. Setiawan, "Digital literacy of preservice science teacher," in Journal of Physics: Conference Series, 2019, vol. 1157, no. 2.

[10] M. Nichols, "A theory for eLearning," J. Educ. Technol. Soc., vol. 6, no. 2, pp. 1-10, 2003.

[11] J. Carwile, "A constructivist approach to online teaching and learning.," Inquiry, vol. 12, no. 1, pp. 68-73, 2007.

[12] C.-W. Tsai, "Improving Undergraduates' Experience of Online Learning: An Approach of Web-Mediated Self-Regulated Learning and Collaborative Learning," in Advances in Computer Science and Education Applications, Springer, 2011, pp. 346349.

[13] P. Boechler, K. Dragon, and E. Wasniewski, "Digital literacy concepts and definitions: Implications for educational assessment and practice," Int. J. Digit. Lit. Digit. Competence, vol. 5, no. 4, pp. 1-18, 2014.

[14] M. D. Osterman, "Digital literacy: Definition, theoretical framework, and competencies," 2013.

[15] A. List, "Defining digital literacy development: An examination of pre-service teachers' beliefs," Comput. Educ., vol. 138, pp. 146-158, 2019.
[16] C. Tagg and P. Seargeant, "Context design and critical language/media awareness: Implications for a social digital literacies education," Linguist. Educ., 2019.

[17] A. Martin, "A European framework for digital literacy," Nord. J. Digit. Lit., vol. 1, no. 02, pp. 151-161, 2006.

[18] H. Uzunboylu, "A review of two mainline e-learning projects in the European Union," Educ. Technol. Res. Dev., vol. 54, no. 2, pp. 201-209, 2006.

[19] B. S. K. Chan, D. Churchill, and T. K. F. Chiu, "Digital literacy learning in higher education through digital storytelling approach," J. Int. Educ. Res., vol. 13, no. 1, pp. 1-16, 2017.

[20] C. McLoughlin, "What ICT-related skills and capabilities should be considered central to the definition of digital literacy?," in EdMedia+ Innovate Learning, 2011, pp. 471-475.

[21] M. Sáinz, C. Castaño, and M. Artal, "Review of the concept of digital literacy and its implications on the study of the gender digital divide," IN3 Work. Pap. Ser., no. 8, 2008.

[22] R. M. Cordell, "Information literacy and digital literacy: Competing or complementary?," Commun. Inf. Lit., vol. 7, no. 2, p. 14, 2013.

[23] H. Silvana and C. Darmawan, "Pendidikan literasi digital di kalangan usia muda di kota bandung," PEDAGOGIA, vol. 16, no. 2, pp. 146-156, 2018

[24] G. Argentin, M. Gui, L. Pagani, and L. Stanca, "The impact of digital literacy on educational outcomes: Evidence from performance tests," Univ. Milan, Bicocca,(August), 2014.

[25] N. Ozdamar-Keskin, F. Z. Ozata, K. Banar, and K. Royle, "Examining digital literacy competencies and learning habits of open and distance learners.," Contemp. Educ. Technol., vol. 6, no. 1, pp. 74-90, 2015.

[26] H. J. Seltman, "Experimental design and analysis," Online http//www. stat. C. edu/, hseltman/309/Book/Book. pdf, 2018.

[27] J. R. Fraenkel, N. E. Wallen, and H. H. Hyun, How to design and evaluate research in education. New York: McGraw-Hill Humanities/Social Sciences/Languages, 2011.

[28] D. T. Campbell and J. C. Stanley, Experimental and quasiexperimental designs for research. Raven Books, 2015.

[29] E. Banowati, T. B. Sanjoto, and others, "The Utilization of Smartphone Communication Technology the as Digital Literacy Learning School Instruments in 4.0 Era," in Journal of Physics: Conference Series, 2019, vol. 1387, no. 1, p. 12111.

[30] S. Patmanthara and W. N. Hidayat, "Improving vocational high school students digital literacy skill through blended learning model," in Journal of Physics: Conference Series, 2018, vol. 1028, no. 1, pp. 1-7.

[31] I. Yuliana, L. P. Octavia, and E. Sudarmilah, "Computational thinking digital media to improve digital literacy." 